\title{
Ecological Determinants of Sporotrichosis Etiological Agents
}

\author{
Max C. Ramírez-Soto ${ }^{1,2, *(1)}$, Elsa G. Aguilar-Ancori ${ }^{3,4}{ }^{\text {, Andrés Tirado-Sánchez }}{ }^{5,6}$ \\ and Alexandro Bonifaz 5 (iD) \\ 1 School of Public Health and Administration, Universidad Peruana Cayetano Heredia, Lima 15102, Peru \\ 2 Fondo Nacional de Desarrollo Científico y Tecnológico y de Innovación Tecnológica (FONDECYT), \\ Consejo Nacional de Ciencia y Tecnologia e Innovacion Tecnologica, Lima 18, Peru \\ 3 Facultad de Ciencias, Universidad Nacional de San Antonio Abad del Cusco (UNSAAC), Cusco 08003, Peru; \\ elsa.aguilar@unsaac.edu.pe \\ 4 Instituto Universitario de Enfermedades Tropicales y Biomedicina del Cusco-UNSAAC, Cusco 08003, Peru \\ 5 Dermatology Service \& Mycology Department, Hospital General de México, "Dr. Eduardo Liceaga", \\ Balmis 148, Colonia Doctores, Ciudad de México 06726, Mexico; atsdermahgm@gmail.com (A.T.-S); \\ a_bonifaz@yahoo.com.mx (A.B.) \\ 6 Internal Medicine Department, Hospital General de Zona 29, Instituto Mexicano del Seguro Social, \\ Ciudad de México 07950, Mexico \\ * Correspondence: maxcrs22@gmail.com; Tel.: +51-984-887-238
}

Received: 29 June 2018; Accepted: 10 August 2018; Published: 12 August 2018

\begin{abstract}
Ecological determinants of sporotrichosis etiological agents remain poorly understood. For this reason, we performed explorations using local climate estimates to determine the temperature and humidity ranges of the environment where clinically relevant Sporothrix species occur and to identify what plant species are associated with them, using data collected from the published literature. We performed a literature search to identify all publications on environmental isolations of medically relevant species of Sporothrix in the PubMed, SCOPUS, and EMBASE databases. All those studies were included in the analysis where medically relevant species of Sporothrix have been isolated from soil samples, and described a specific geographical location that could be precisely georeferenced. We approximated temperature and humidity from local climate estimates, integrating geospatial data, temperature, and water vapor pressure from regions or provinces where medically relevant species of Sporothrix have been isolated from soil. Sporothrix spp. were more commonly isolated from soil of different regions or provinces of 16 countries. Most environmental isolates were identified as S. schenckii, whereas S. pallida, S. brasiliensis, S. globosa, and S. mexicana were rare. We estimate that medically relevant Sporothrix spp. grow in the soil at temperatures of $6.6^{\circ} \mathrm{C}$ to $28.84^{\circ} \mathrm{C}$ and $37.5 \%$ to $99.06 \%$ relative humidity. These findings indicate that sporotrichosis etiological agents grow in soil in ecological niches from soil with wide ranges of temperature and humidity, but they are also associated with a variety of plants, flowers, woody debris, reed leaves, corn stalks, leaves, and wood crumbs, potentially facilitating its establishment and proliferation in the environment.
\end{abstract}

Keywords: ecological determinants; Sporothrix spp.; temperature; humidity

\section{Introduction}

Sporotrichosis is an implantation mycosis caused by the Sporothrix spp. [1,2]. It is prevalent in tropical and subtropical areas, and the incidence varies from country to country, with high-prevalence areas located within these endemic focuses [2,3]. Sporothrix is a saprophyte of organic matter, dead wood, mosses, hay, and cornstalks [2,4]. It has specific ecological niches within endemic areas, and it grows in soil at a temperature range between $22{ }^{\circ} \mathrm{C}$ and $27^{\circ} \mathrm{C}$, pH between 3.5 and 9.4 , and $90 \%$ 
humidity [2-5]. Currently, species groups of Sporothrix that are medically relevant include S. schenckii (sensu stricto), S. brasiliensis, S. globosa, S. luriei, S. mexicana, and S. pallida [6,7].

Although the geographic distribution of the sporotrichosis is well-characterized [1,3], and it is known that the soil, thorny plants, sphagnum moss, and even certain animals are the reservoirs for sporotrichosis [2-4], the association between its etiological agents and ecological factors largely remains uncharacterized. This supports the need to study the possible effects of temperature and humidity of environments where the Sporothrix spp. grows. Due to this, we performed explorations using local climate estimates to determine the temperature and humidity ranges of regions where the Sporothrix spp. grows, and to identify what plant species were associated with the Sporothrix spp., using data collected from the published literature. We focused solely on environmental isolations of medically relevant species of Sporothrix (S. schenckii, S. brasiliensis, S. globosa, S. mexicana, S. pallida, and S. luriei).

\section{Materials and Methods}

\subsection{Literature Search}

We performed a literature search of all publications on environmental and soil isolations of Sporothrix in the PubMed, SCOPUS, and EMBASE databases up until May 20th, 2018. We also searched the reference lists of the included articles. We applied the Preferred Reporting Items for Systematic Reviews and Meta-Analyses statement (PRISMA) to the methods for this study [8]. Search terms included combinations of the following keywords: environmental, Sporothrix, soil, and ecological.

\subsection{Inclusion and Exclusion Criteria}

All studies where medically relevant species of Sporothrix have been isolated from soil samples, and which described a specific geographic location that could be georeferenced precisely, were included in the analysis. We excluded studies where the fungus was isolated from a human or animal case, and studies where the geographical boundary of the study area was poorly-defined.

\subsection{Data Collected}

The following data was collected: name of the author(s), year, region, the environment where Sporothrix spp. has been isolated, the molecular type of the Sporothrix species, and vegetal species associated with the Sporothrix fungus.

\subsection{Statistical Analysis}

Since exact coordinates were not specified by the studies where medically relevant species of Sporothrix were isolated, latitude, longitude, and elevation coordinates from these regions or provinces were obtained from Google Earth (www.earth.google.com/) by georeferencing [9]. Coordinates for the regions or province were taken based on the centroid of the city, town, or region where samples were taken. To obtain temperature and water vapor pressure $(\mathrm{hPa})$, latitude, longitude, and elevation coordinates obtained from Google Earth were deposited in a software from local climate estimating 'LocClim 1.0' (http:/ / www.fao.org/nr/climpag/pub/en0201_en.asp). The distance of the neighboring stations was configured at a distance of at least $500 \mathrm{~km}$. Annual average temperature and water vapor pressure data were obtained after locating the region or province where medically relevant species of Sporothrix were isolated. To determine the saturated vapor pressure and relative humidity (\%) of the environment, the following equations were used, as described previously [10]:

$$
\begin{gathered}
\mathrm{e}_{\mathrm{s}}=6.11 \times 10^{\frac{(7.5 \times \mathrm{T})}{(273.3+\mathrm{T})}} \\
\mathrm{RH}=\frac{\mathrm{e}}{\mathrm{e}_{\mathrm{s}}} \times 100
\end{gathered}
$$


$\mathrm{e}_{\mathrm{s}}$ : saturated steam pressure

T: temperature

e: current steam pressure

RH: relative humidity (\%)

\section{Results}

\subsection{Studies Included}

The searches identified 212 records. After 212 titles and abstracts were reviewed, 189 records that did not meet the inclusion criteria were excluded. Finally, 23 studies that reported environmental and soil isolations of medically relevant Sporothrix spp. were included [11-33].

\subsection{The Geographical Distribution of Environmental Isolations of Sporothrix spp.}

Sporothrix spp. were isolated from the environment of regions or provinces of Argentina, Austria, Brazil, Chile, China, Germany, India, Israel, Italy, Mexico, Spain, South Africa, Netherlands, United States, Uruguay, and Venezuela. Isolations were most commonly recovered from the provinces of Mexico (Figure 1 and Table 1).

\subsection{Sources of Environmental Isolations of Sporothrix spp.}

In this review, environmental isolates of Sporothrix were recovered from different environmental sources. Isolations were mostly obtained from the soil. Other sources were of leaves, flowers, woody debris, reed leaves, old reed leaves, corn stalks, old corn stalks, leaves, and wood crumbs (Table 1).

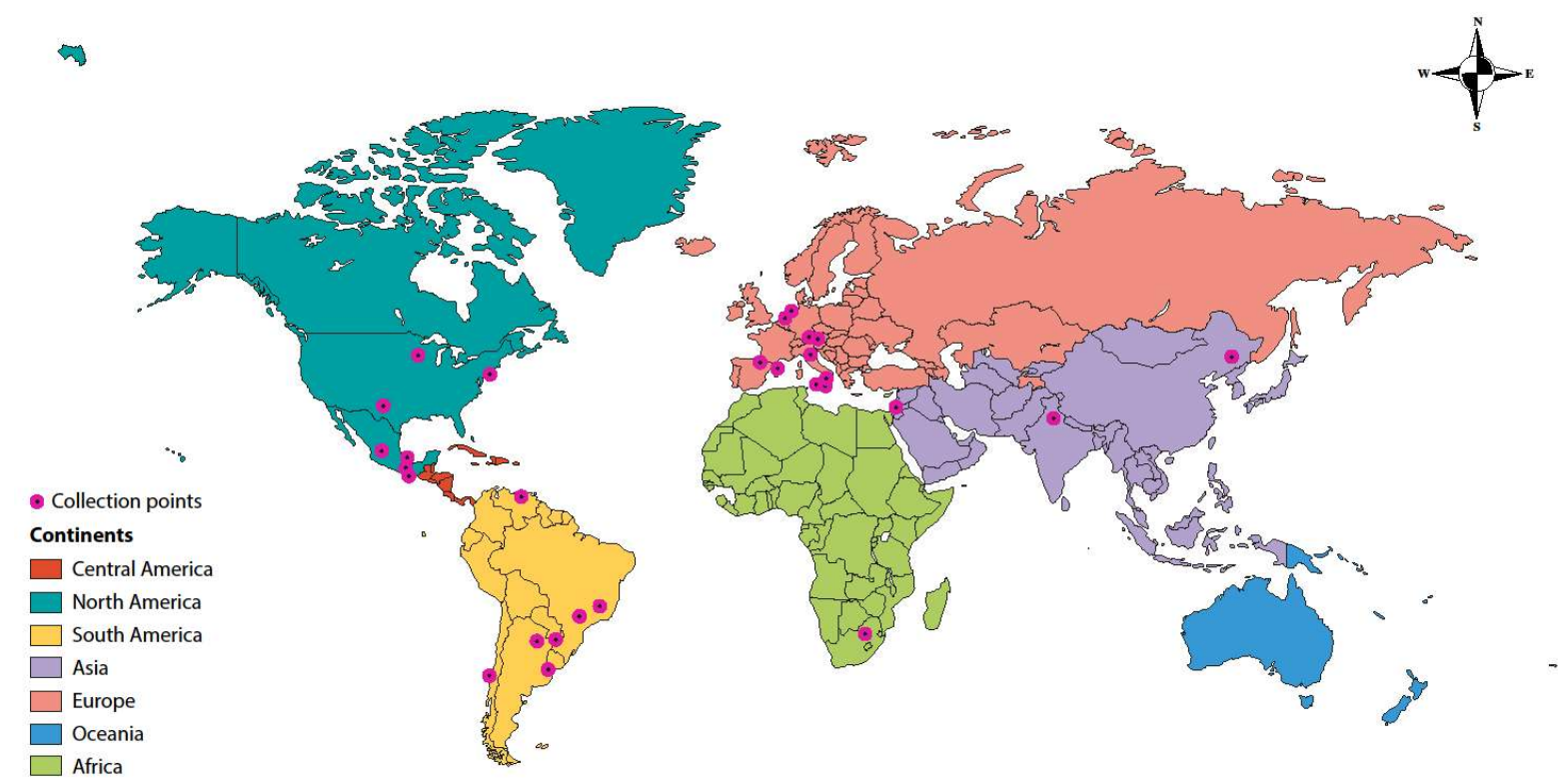

Figure 1. Geographic distribution of environmental isolations of medically relevant Sporothrix spp. 
Table 1. Studies overview environmental and soil isolations of medically relevant Sporothrix spp.

\begin{tabular}{|c|c|c|c|c|c|c|c|c|c|c|c|}
\hline Country & Ref. & $\begin{array}{l}\text { Collection } \\
\text { Year }\end{array}$ & Region & $\begin{array}{l}\text { Molecular } \\
\text { Identification }\end{array}$ & Source & Species & Longitude * & Latitude * & $\begin{array}{l}\text { Elevation } \\
\text { (Meters) * }\end{array}$ & $\begin{array}{c}\text { Temperature } \\
\left({ }^{\circ} \mathrm{C}\right)^{*}\end{array}$ & $\mathbf{R H}(\%) *$ \\
\hline \multirow[t]{3}{*}{ Argentina } & [11] & 2003 & Chaco & S. brasiliensis & Soil & S. brasiliensis & $-59.018371^{\circ}$ & $-27.420760^{\circ}$ & 53 & 20.92 & 89.21 \\
\hline & & 2004 & Chaco & S. schenckii & Soil & S. schenckii & & & & & \\
\hline & & 2001 & Misiones & S. schenckii & Soil & S. schenckii & $-55.960100^{\circ}$ & $-27.443478^{\circ}$ & 153 & 21.14 & 89.15 \\
\hline Austria & [12] & 2007-2008 & Salzburg, Austria & S. schenckii & Garden soil & S. schenckii & $13.051580^{\circ}$ & $47.810801^{\circ}$ & 429 & 8.91 & 86.91 \\
\hline \multirow[t]{2}{*}{ Brazil } & [13] & 2014 & $\begin{array}{l}\text { Botucato, Sauñe } \\
\text { Paulo }\end{array}$ & $\begin{array}{l}\text { S. schenckii } \\
\text { (sensu stricto) }\end{array}$ & Armadillo soil & $\begin{array}{l}\text { S. schenckii } \\
\text { (sensu stricto) }\end{array}$ & $-48.437236^{\circ}$ & $-22.892863^{\circ}$ & 793 & 19.19 & 87.88 \\
\hline & [14] & 1963 & $\begin{array}{l}\text { Piracicaba and } \\
\text { Vicinity }\end{array}$ & $\cdots$ & Soil & S. schenckii & $-43.905655^{\circ}$ & $-19.926731^{\circ}$ & 904 & 19.54 & 95.97 \\
\hline \multirow[t]{3}{*}{ Chile } & [15] & 2012 & Valparaiso & $\ldots$ & Soil & S. globosa & $-71.595196^{\circ}$ & $-33.094955^{\circ}$ & 460 & 12.66 & 87.35 \\
\hline & {$[16]$} & 2014 & Viña del Mar & S. pallida & Garden soil & S. pallida & $-71.549622^{\circ}$ & $-33.012123^{\circ}$ & 17 & 14.76 & 85.95 \\
\hline & [17] & 2016 & Viña del Mar & S. chilensis & Garden soil & S. chilensis & & & & & \\
\hline China & [18] & 2002 & Jilin & S. schenckii & $\begin{array}{c}\text { Soil, reed leaves, old reed } \\
\text { leaves, corn stalks and old } \\
\text { corn stalks, Cettal leaves, and } \\
\text { wood crumbs }\end{array}$ & S. schenckii & $126.414149^{\circ}$ & $43.144094^{\circ}$ & 521 & 6.60 & 78.42 \\
\hline Germany & [12] & 2007-2008 & $\begin{array}{l}\text { Rain Am Lech, } \\
\text { Germany }\end{array}$ & S. schenckii & Amended soil & S. schenckii & $10.922538^{\circ}$ & $48.690341^{\circ}$ & 412 & 8.24 & 91.41 \\
\hline Israel & [20] & 1976 & Petah Tiqua & & Soil & S. schenckii & $34.887816^{\circ}$ & $32.083751^{\circ}$ & 57 & 19.35 & 79.73 \\
\hline \multirow[t]{8}{*}{ Italy } & [12] & $2007-2008$ & Reggio Calabria & S. schenckii & Natural soil & S. schenckii & $15.661199^{\circ}$ & $38.102348^{\circ}$ & 62 & 18.01 & 84.86 \\
\hline & & & Serra San Bruno & S. schenckii & Sphagnum moss & S. schenckii & $16.314224^{\circ}$ & $38.562623^{\circ}$ & 830 & 12.14 & 86.58 \\
\hline & & & Reggio Calabria & S. schenckii & Amended soil & S. schenckii & $15.638878^{\circ}$ & $38.104305^{\circ}$ & 8 & 18.42 & 84.6 \\
\hline & & & Verona & S. schenckii & Garden soil & S. schenckii & $10.994555^{\circ}$ & $45.448563^{\circ}$ & 59 & 13.29 & 86.19 \\
\hline & & & Calabria & S. schenckii & Enviromental & S. schenckii & $16.349470^{\circ}$ & $39.312534^{\circ}$ & 857 & 11.91 & 83.69 \\
\hline & & & Sicily & S. schenckii & Enviromental & S. schenckii & $14.038756^{\circ}$ & $37.598328^{\circ}$ & 507 & 15.38 & 81.74 \\
\hline & [21] & 2007 & Huauchinango-Puebla & $\cdots$ & $\begin{array}{l}\text { Soil associated with pine, rose, } \\
\text { gladiolus and wild plant }\end{array}$ & S. schenckii & $-98.062507^{\circ}$ & $20.175399^{\circ}$ & 1553 & 16.23 & 99.06 \\
\hline & [22] & 2004 & $\begin{array}{c}\text { Santa Maria } \\
\text { quielogani, Oaxaca }\end{array}$ & $\cdots$ & Farmland & S. schenckii & $-96.056315^{\circ}$ & $16.278295^{\circ}$ & 2061 & 28.84 & 37.5 \\
\hline \multirow[t]{3}{*}{ Mexico } & [23] & 2017 & Atlixco & $\ldots$ & Soil & S. schenckii & $-98.429715^{\circ}$ & $18.911546^{\circ}$ & 1842 & 18.74 & 78.34 \\
\hline & & & Cholula & $\ldots$ & Soil & S. schenckii & $-98.300998^{\circ}$ & $19.076175^{\circ}$ & 2168 & 16.79 & 73.49 \\
\hline & & & $\begin{array}{l}\text { Izúcar de } \\
\text { Matamoros }\end{array}$ & $\cdots$ & Soil & S. schenckii & $-98.464283^{\circ}$ & $18.598513^{\circ}$ & 1285 & 22.95 & 83.63 \\
\hline
\end{tabular}


Table 1. Cont.

\begin{tabular}{|c|c|c|c|c|c|c|c|c|c|c|c|}
\hline Country & Ref. & $\begin{array}{l}\text { Collection } \\
\text { Year }\end{array}$ & Region & $\begin{array}{l}\text { Molecular } \\
\text { Identification }\end{array}$ & Source & Species & Longitude * & Latitude * & $\begin{array}{l}\text { Elevation } \\
\text { (Meters) * }\end{array}$ & $\begin{array}{c}\text { Temperature } \\
\left({ }^{\circ} \mathrm{C}\right) *\end{array}$ & $\mathbf{R H}(\%)$ * \\
\hline & & & Tecali de Herrera & $\ldots$ & Soil & S. schenckii & $-97.974147^{\circ}$ & $18.901923^{\circ}$ & 2175 & 16.88 & 72.18 \\
\hline & & & Tecamachalco & $\ldots$ & Soil & S. schenckii & $-97.733545^{\circ}$ & $18.879810^{\circ}$ & 2015 & 18.23 & 70.32 \\
\hline & & & Tehuacan & $\ldots$ & Soil & S. schenckii & $-97.393711^{\circ}$ & $18.466471^{\circ}$ & 1640 & 19.04 & 79.37 \\
\hline & & & Tepexi de Rodriguez & $\ldots$ & Soil & S. schenckii & $-97.928542^{\circ}$ & $18.584326^{\circ}$ & 1690 & 21.02 & 72.53 \\
\hline & & & Atlixco & $\ldots$ & $\begin{array}{l}\text { Soil associated with } \\
\text { Eucalyptus camaldulensis, Rosa } \\
\text { centifolia, Zea mays }\end{array}$ & S. schenckii & $-98.437736^{\circ}$ & $18.912245^{\circ}$ & 1940 & 17.96 & 78.22 \\
\hline \multirow[t]{7}{*}{ Mexico } & [23] & 2017 & $\begin{array}{l}\text { Izúcar de } \\
\text { Matamoros }\end{array}$ & $\cdots$ & $\begin{array}{c}\text { Curcurbita sp., Stenocereus } \\
\text { marginatus, and Cupressus } \\
\text { lindleyi }\end{array}$ & S. schenckii & $-98.461786^{\circ}$ & $18.579067^{\circ}$ & 1266 & 23.23 & 79.85 \\
\hline & & & Puebla & $\cdots$ & $\begin{array}{l}\text { Jacaranda mimosaefalia and } \\
\text { Oreodoxa regia (palma) }\end{array}$ & S. schenckii & $-98.207416^{\circ}$ & $19.047159^{\circ}$ & 2163 & 17.00 & 75.18 \\
\hline & & & Tecali de Herrera & $\ldots$ & Plants & S. schenckii & $-97.973964^{\circ}$ & $18.914850^{\circ}$ & 2186 & 16.79 & 72.11 \\
\hline & & & Tecamachalco & $\ldots$ & Plants & S. schenckii & $-97.749386^{\circ}$ & $18.882578^{\circ}$ & 2015 & 19.39 & 66.48 \\
\hline & & & Tehuacan & $\ldots$ & Plants & S. schenckii & $-97.371094^{\circ}$ & $18.465983^{\circ}$ & 1562 & 19.37 & 80.43 \\
\hline & & & Tepexi de Rodriguez & $\ldots$ & Plants & S. schenckii & $-97.920730^{\circ}$ & $18.585191^{\circ}$ & 1655 & 21.27 & 72.53 \\
\hline & & & Guadalajara & $\ldots$ & Brachiaria plataginea & S. schenckii & $-103.442383^{\circ}$ & $20.595692^{\circ}$ & 1627 & 19.33 & 69.28 \\
\hline \multirow{4}{*}{ Mexico } & & & Zapopan & $\ldots$ & Soil & S. schenckii & $-103.415036^{\circ}$ & $20.671554^{\circ}$ & 1626 & 19.30 & 68.83 \\
\hline & [25] & 2009 & $\begin{array}{l}\text { Huachinango } \\
\text { Puebla }\end{array}$ & S. schenckii & Soil & S. schenckii & $-98.062507^{\circ}$ & $20.175399^{\circ}$ & 1553 & 16.23 & 99.06 \\
\hline & & & Xilocuautla Puebla & S. schenckii & Soil & S. schenckii & $-98.023551^{\circ}$ & $20.138984^{\circ}$ & 1630 & 15.50 & 98.85 \\
\hline & & & $\begin{array}{c}\text { San Andrés } \\
\text { Larraizar Chiapas }\end{array}$ & S. schenckii & Soil & S. schenckii & $-92.712955^{\circ}$ & $16.882654^{\circ}$ & 2220 & 16.54 & 72.09 \\
\hline \multirow[t]{2}{*}{ Spain } & [12] & $2007-2008$ & Barcelona & S. schenckii & Amended soil & S. schenckii & $2.185471^{\circ}$ & $41.387742^{\circ}$ & 8 & 16.85 & 81.33 \\
\hline & & $2007-2008$ & Navarra & S. schenckii & Garden soil & S. schenckii & $-1.652109^{\circ}$ & $42.817402^{\circ}$ & 442 & 12.42 & 79.29 \\
\hline \multirow[t]{2}{*}{$\begin{array}{l}\text { South } \\
\text { Africa }\end{array}$} & [26] & 1986 & Pretoria & $\cdots$ & Soil & S. schenckii & $28.184889^{\circ}$ & $-25.742540^{\circ}$ & 1311 & 18.24 & 65.89 \\
\hline & [27] & 2014 & South Africa & S. mexicana & Soil of mines & S. mexicana & $28.070048^{\circ}$ & $-26.229788^{\circ}$ & 1684 & 16.15 & 68.52 \\
\hline $\begin{array}{l}\text { The } \\
\text { Netherlands }\end{array}$ & [28] & 2008 & $\begin{array}{c}\text { Centraalbureau voor } \\
\text { Schimmelcultures, } \\
\text { Utrecht }\end{array}$ & S. pallida & Garden soil & S. pallida & $5.176516^{\circ}$ & $52.089437^{\circ}$ & 0 & 9.44 & 93.98 \\
\hline
\end{tabular}


Table 1. Cont.

\begin{tabular}{|c|c|c|c|c|c|c|c|c|c|c|c|}
\hline Country & Ref. & $\begin{array}{l}\text { Collection } \\
\text { Year }\end{array}$ & Region & $\begin{array}{l}\text { Molecular } \\
\text { Identification }\end{array}$ & Source & Species & Longitude * & Latitude * & $\begin{array}{l}\text { Elevation } \\
\text { (Meters) * }\end{array}$ & $\begin{array}{l}\text { Temperature } \\
\left({ }^{\circ} \mathrm{C}\right)^{*}\end{array}$ & $\mathbf{R H}(\%) *$ \\
\hline & [12] & $2007-2008$ & Vriezenveen & S. schenckii & Amended soil & S. schenckii & $6.614617^{\circ}$ & $52.408313^{\circ}$ & 11 & 9.14 & 95.32 \\
\hline \multirow{3}{*}{$\begin{array}{l}\text { United } \\
\text { States }\end{array}$} & [29] & 1970 & Winsconsisn & $\cdots$ & $\begin{array}{l}\text { Soil, wood, sphagnum were } \\
\text { assayed for pathogenic fungi }\end{array}$ & S. schenckii & $-88.492690^{\circ}$ & $43.767366^{\circ}$ & 244 & 7.63 & 93.55 \\
\hline & [30] & 1988 & New York & $\ldots$ & Sphagnum moss & S. schenckii & $-73.978368^{\circ}$ & $40.732011^{\circ}$ & 3 & 12.67 & 82.41 \\
\hline & [31] & 1984 & Texas & $\ldots$ & Potting soil & S. schenckii & $-99.955168^{\circ}$ & $31.958474^{\circ}$ & 558 & 18.05 & 72.66 \\
\hline Uruguay & [32] & 1969 & Montevideo & $\cdots$ & $\begin{array}{l}\text { Soil and plant remains, } \\
\text { armadillo soil, moss floors, } \\
\text { dry grassland of } \\
\text { armadillo nest }\end{array}$ & S. schenckii & $-56.207668^{\circ}$ & $-34.859734^{\circ}$ & 12 & 17.10 & 83.48 \\
\hline Venezuela & [33] & 2007 & $\begin{array}{c}\text { Estado } \\
\text { Aragua-Caracas }\end{array}$ & $\cdots$ & $\begin{array}{l}\text { Land with and without } \\
\text { fertilizer }\end{array}$ & S. schenckii & $-67.278619^{\circ}$ & $10.231817^{\circ}$ & 547 & 23.47 & 96.62 \\
\hline
\end{tabular}

* Coordinates, temperature, and relative humidity obtained in the present study. RH: relative humidity. 


\subsection{Identified Sporothrix spp.}

Six Sporothrix spp. were identified. In most reports, identification of Sporothrix spp. was carried out using standard phenotypic methods (macroscopic and microscopic characteristics of the fungus). Additional established molecular methods were also used to identify the Sporothrix spp. (S. schenckii s. str., S. pallida, S. brasiliensis, S. globosa, S. chilensis, and S. mexicana). Most environment isolates were identified as S. schenckii, whereas S. pallida (2 isolates), S. brasiliensis (1 isolate), S. globosa (1 isolate), S. chilensis (1 isolate), and S. mexicana (1 isolate) were rare. S. schenckii was identified in Argentina, Austria, Brazil, China, Germany, India, Israel, Italy, Spain, Netherlands, United States, Uruguay, and Venezuela. Mexico had the highest number of S. schenckii isolates identified. S. globosa, S. pallida and S. chilensis were isolated in Chile, S. brasiliensis in Argentina, S. mexicana in South Africa, and S. pallida in The Netherlands (Table 1).

\subsection{Temperature and Relative Humidity}

Since temperature and relative humidity were not specified by the 21 studies where medically relevant species of Sporothrix were isolated, we estimated the temperature and relative humidity ranges of the environments where the Sporothrix fungus grows. Overall, we estimate that medically relevant Sporothrix spp. have specific ecological niches within endemic areas, and they grow in the environment of soil at a temperature between $6.6^{\circ} \mathrm{C}$ and $28.84{ }^{\circ} \mathrm{C}$, and relative humidity between $37.5 \%$ and $99.06 \%$.

The temperature and relative humidity ranges of the environments where Sporothrix fungus grows showed great variations, even in cases where the distributions were within the same country. For example, in Mexico S. schenckii grows in the soil at temperatures of $16.23{ }^{\circ} \mathrm{C}$ to $28.84{ }^{\circ} \mathrm{C}$ and $37.5 \%$ to $99.06 \%$ relative humidity, whereas in the United States, it grows in the soil at temperatures of $7.63{ }^{\circ} \mathrm{C}$ to $18.05^{\circ} \mathrm{C}$ and $72.66 \%$ to $93.55 \%$ relative humidity. In Latin America, S. schenckii grows in the soil in Brazil at a temperature of $19.09{ }^{\circ} \mathrm{C}$ and $87.88 \%$ relative humidity, in Chaco-Argentina S. brasiliensis and S. schenckii s. str. grow in the soil at a temperature of $20.92{ }^{\circ} \mathrm{C}$ and $89.21 \%$ relative humidity, in Chile S. globosa and S. pallida grows in the soil at temperatures of $12.66{ }^{\circ} \mathrm{C}$ to $14.76{ }^{\circ} \mathrm{C}$ and $85.95 \%$ to $87.35 \%$ relative humidity, and in Uruguay and Venezuela S. schenckii s. str. grows in the soil at temperatures of $17.1^{\circ} \mathrm{C}$ and $23.47{ }^{\circ} \mathrm{C}$ and $83.48 \%$ and $96.62 \%$ relative humidity, respectively (Table 1 ).

In Asia, S. schenckii grows in the soil in China at a temperature of $6.6^{\circ} \mathrm{C}$ and $78.42 \%$ relative humidity, and in India S. schenckii grows in the soil at a temperature of $15.48{ }^{\circ} \mathrm{C}$ and $68.22 \%$ relative humidity. In South Africa, S. schenckii and S. mexicana grows in the soil at temperatures of $16.15^{\circ} \mathrm{C}$ to $18.24{ }^{\circ} \mathrm{C}$ and $65.89 \%$ to $68.52 \%$ relative humidity (Table 1 ).

\section{Discussion}

The survival of fungi in their environmental niches depends on their ability to adapt to changing conditions [4]. Isolation of $S$. schenckii from nature has been reported both in endemic and non-endemic areas in various environmental conditions [11-33]. Our findings indicated that Sporothrix spp. are isolated mostly from soil, but they are also associated with a variety of plants, flowers, woody debris, reed leaves, corn stalks, leaves, and wood crumbs [11-33], potentially facilitating its establishment and proliferation in the environment. Therefore, it will take advantage of the opportunity to infect a mammal host, including humans, cats, and dogs [34]. Sporotrichosis is often referred to as 'rose handler's disease', since the fungus has long been thought to be acquired by means of trauma associated with rose bush spines and other plant materials as Sphagnum moss [1-3]. The sprouts responsible for propagation or vegetative reproduction in plants, also called propagules, usually present in the state of nature, are the main source of infection for the patients with sporotrichosis, through a traumatic inoculation in Tropical and Subtropical zones. The soil constitutes another reservoir of the fungus, as well as some insects like beetles and ants [13].

Although the geographical distribution of clinically-relevant Sporothrix species has been intensively studied, these fungi have been hard to isolate from the environment probably due to 
their low concentration in environmental samples. In addition, Sporothrix spp. are slow-growing fungi, and on rich culture media, their colonies are easily obscured by fast growing molds such as Penicillium, Aspergillus, or Mucorales [35]. In the present study, six Sporothrix spp. were identified as S. schenckii s. str., S. pallida, S. brasiliensis, S. globosa, S. chilensis, and S. mexicana. The different species of the so-called Sporothrix schenckii complex are environmental fungi found in soils, plants, water, decaying plants, and other outdoor environments [4,5]. Although they have been isolated from diverse environments, few studies have pointed to the influence of the environment (temperature and humidity) on the virulence of these pathogens. However, some research in S. schenckii and other cryptic species suggest that adverse conditions in the natural habitat may trigger the expression of different virulence factors, conferring survival advantages both in the environment and in the host tissue [4].

Environmental microorganisms are usually exposed to different physical factors, such as extreme temperatures, salinity, sunlight (in direct relation with latitude), and drought. S. schenckii is able to withstand extreme conditions, such as very low temperatures $[36,37]$ and extreme osmotic pressure $[2,38]$ for several years. Similarly, there is evidence that $S$. schenckii is able to resist the influence of solar radiation. The exposure of $S$. schenckii to different levels of UV light results in a conserved viability [39,40]. The environmental stressor promotes the virulence of S. schenckii; the origin of virulence in S. schenckii must be related to the interactions of the pathogen with the different environmental challenges present in its natural habitat, such as extreme temperatures (highs and lows), as we observed in our study, where the isolation was made in geographical areas with extreme temperatures, humidity/drought, radiation, and chemical contamination. These environmental stressors are tolerated due to constitutive fungal structures and inducible molecules acquiring survival capacity and becoming virulence factors in the infected host. The interaction of dimorphic fungi with a mammalian host is not a requirement for the survival and virulence of fungi, as in the case with other pathogenic microorganisms [39]. This phenomenon is called "ready-to-use" virulence [40] and the environment may contribute to the origin and maintenance of virulence in certain fungi [41-46]. One of the virulence factors of Sporothrix spp. is their ability to convert to yeast phase when they enter the human body. However, a non-clinical species, 'Ophiostoma' bragantinum with a Sporothrix asexual morph, is able to convert into yeast cells when it is grown at temperatures near $30^{\circ} \mathrm{C}$. The ability to form yeast cells might be widely present in the genus Sporothrix [47]. Although many external influences are known to affect the pathogenicity of the $S$. schenckii complex, these influences and mechanisms have not been sufficiently studied. However, the existence of common molecules that interact with environmental stressors, described in various environmental fungi, leads us to the hypothesis that similar mechanisms may be acting in S. schenckii, regarding their adaptation to these extreme conditions [4]. Several virulence factors can be produced by fungi to survive both in animal hosts and in the environment. This phenomenon is called "dual use" [48]. Understanding the interactions between fungi and their potential hosts in the environment is in its initial stage. However, initial observations suggest that this will be an extremely rich area of research to further explore fundamental issues of fungal pathogenesis $[49,50]$.

The limitations of our study are the relatively few published reports and methods used. Regarding the former, only 23 studies of 16 countries were included, since published reports on Sporothrix show that clinical and veterinary isolations have always outnumbered environmental isolations. Regarding the latter, according to the methods used to estimate the temperature and humidity ranges of environments where the Sporothrix fungus grows, our findings only provide an approximate estimate of temperature and humidity ranges in certain regions of the countries studied. However, these data can also constitute gross underestimations or overestimations of the true temperature and the humidity of the environment where the Sporothrix spp. grows. Finally, several apparently non-pathogenic species (e.g., S. brunneoviolacea, S. dimorphospora and S. inflata) are morphologically very similar to S. schenckii and its pathogenic relatives. Therefore, reports of isolations not supported by DNA sequence data may sometimes represent misidentifications. Despite these limitations, our findings may contribute to the design of new strategies for the control of sporotrichosis in the future. 


\section{Conclusions}

Although limited, the results of our study indicate that sporotrichosis etiological agents grow in soil ecological niches from soil with wide ranges in temperature and humidity, but they are also associated with a variety of plants, flowers, woody debris, reed leaves, corn stalks, leaves, and wood crumbs, potentially facilitating its establishment and proliferation in the environment. Therefore, more studies that evaluate the influence of different environmental factors on the physiology and pathogenicity of the $S$. schenckii complex are necessary, although all available data suggests the existence of strategies that pathogenic fungi acquire to survive adverse environmental conditions. In turn, these mechanisms of acquired resistance provide the fungi with the ability to infect animals and can allow the emergence of opportunistic pathogens from these microenvironments [49].

Author Contributions: Conceptualization, M.C.R.-S.; Formal analysis, M.C.R.-S., E.G.A.-A., A.T.-S. and A.B.; Investigation, M.C.R.-S., E.G.A.-A., A.T.-S. and A.B.; Methodology, M.C.R.-S., E.G.A.-A., A.T.-S. and A.B.; Supervision, M.C.R.-S.; Writing-original draft, M.C.R.-S., A.T.-S. and A.B.; Writing-review \& editing, M.C.R.-S., E.G.A.-A., A.T.-S. and A.B.

Funding: This research received no external funding.

Acknowledgments: The authors wish to thank Luis Eduardo Cano Carrasco (Facultad de Ciencias, Universidad Nacional de San Antonio Abad del Cusco, Cusco city, Peru) for the information provided.

Conflicts of Interest: The authors declare no conflict of interest.

\section{References}

1. Queiroz-Telles, F.; Nucci, M.; Colombo, A.L.; Tobón, A.; Restrepo, A. Mycoses of implantation in Latin America: An overview of epidemiology, clinical manifestations, diagnosis and treatment. Med. Mycol. 2011, 49, 225-236. [CrossRef] [PubMed]

2. Barros, M.B.; de Almeida Paes, R.; Schubach, A.O. Sporothrix schenckii and Sporotrichosis. Clin. Microbiol. Rev. 2011, 24, 633-654. [CrossRef] [PubMed]

3. Chakrabarti, A.; Bonifaz, A.; Gutierrez-Galhardo, M.C.; Mochizuki, T.; Li, S. Global epidemiology of sporotrichosis. Med. Mycol. 2015, 53, 3-14. [CrossRef] [PubMed]

4. Téllez, M.D.; Batista-Duharte, A.; Portuondo, D.; Quinello, C.; Bonne-Hernández, R.; Carlos, I.Z. Sporothrix schenckii complex biology: Environment and fungal pathogenicity. Microbiology 2014, 160 Pt 11, 2352-2365. [CrossRef]

5. Noriega, C.T.; Garay, R.R.; Sabanero, G.; Basurto, R.T.; Sabanero-Lopez, M. Sporothrix schenckii: Cultures in different soils. Rev. Latinoam. Micol. 1993, 35, 191-194. (In Spanish)

6. Lopes-Bezerra, L.M.; Mora-Montes, H.M.; Zhang, Y.; Nino-Vega, G.; Rodrigues, A.M.; de Camargo, Z.P.; de Hoog, S. Sporotrichosis between 1898 and 2017: The evolution of knowledge on a changeable disease and on emerging etiological agents. Med. Mycol. 2018, 56, 126-143. [CrossRef] [PubMed]

7. Marimon, R.; Cano, J.; Gené, J.; Sutton, D.A.; Kawasaki, M.; Guarro, J. Sporothrix brasiliensis, S. globosa, and S. mexicana, Three New Sporothrix Species of Clinical Interest. J. Clin. Microbiol. 2007, 45, 3198-3206. [CrossRef] [PubMed]

8. Liberati, A.; Altman, D.G.; Tetzlaff, J.; Mulrow, C.; Gøtzsche, P.C.; Ioannidis, J.P.; Clarke, M.; Devereaux, P.J.; Kleijnen, J.; Moher, D. The PRISMA statement for reporting systematic reviews and meta-analyses of studies that evaluate healthcare interventions: Explanation and elaboration. BMJ 2009, 339, b2700. [CrossRef] [PubMed]

9. Samy, A.M.; van de Sande, W.W.J.; Fahal, A.H.; Peterson, A.T. Mapping the potential risk of mycetoma infection in Sudan and South Sudan using ecological niche modeling. PLoS Negl. Trop. Dis. 2014, 8, e3250. [CrossRef] [PubMed]

10. Oyj, V. Humidity Conversion Formulas_Calculation Formulas for Humidity; Vaisala: Helsinki, Finland, 2013.

11. Córdoba, S.; Isla, G.; Szusz, W.; Vivot, W.; Hevia, A.; Davel, G.; Canteros, C.E. Molecular identification and susceptibility profile of Sporothrix schenckii sensu lato isolated in Argentina. Mycoses 2018, 61, 441-448. [CrossRef] [PubMed]

12. Criseo, G.; Romeo, O. Ribosomal DNA Sequencing and Phylogenetic Analysis of Environmental Sporothrix schenckii Strains: Comparison with Clinical Isolates. Mycopathologia 2010, 169, 351-358. [CrossRef] [PubMed] 
13. Rodrigues, A.M.; Bagagli, E.; de Camargo, Z.P.; de Moraes Gimenes Bosco, S. Sporothrix schenckii sensu stricto isolated from Soil in an Armadillo's Burrow. Mycopathologia 2014, 177, 199-206. [CrossRef] [PubMed]

14. Rogers, A.L.; Beneke, E.S. Human pathogenic fungi recovered from Brazil soil. Mycopathol. Mycol. Appl. 1964, 22, 15-20. [CrossRef] [PubMed]

15. Cruz, R.; Vieille, P.; Oschilewski, D. Sporothrix globosa isolation related to a case of lymphocutaneous sporotrichosis. Rev. Chil. Infectol. 2012, 29, 401-405. (In Spanish) [CrossRef] [PubMed]

16. Cruz Choappa, R.M.; Vieille Oyarzo, P.I.; Carvajal Silva, L.C. Isolation of Sporothrix pallida complex in clinical and environmental samples from Chile. Rev. Argent. Microbiol. 2014, 46, 311-314. [PubMed]

17. Rodrigues, A.M.; Cruz Choappa, R.; Fernandes, G.F.; de Hoog, G.S.; de Camargo, Z.P. Sporothrix chilensis sp. nov. (Ascomycota: Ophiostomatales), a soil-borne agent of human sporotrichosis with mild-pathogenic potential to mammals. Fungal Biol. 2016, 120, 246-264. [CrossRef] [PubMed]

18. Ishizaki, H.; Kawasaki, M.; Mochizuki, T.; Jin, X.Z.; Kagawa, S. Environmental isolates of Sporothrix schenckii in China. Nihon Ishinkin Gakkai Zasshi 2002, 43, 257-260. [CrossRef] [PubMed]

19. Mehta, K.I.; Sharma, N.L.; Kanga, A.K.; Mahajan, V.K.; Ranjan, N. Isolation of Sporothrix schenckii from the environmental sources of cutaneous sporotrichosis patients in Himachal Pradesh, India: Results of a pilot study. Mycoses 2007, 50, 496-501. [CrossRef] [PubMed]

20. Feuerman, E.J.; Alteras, I.; Bashan, D.; Lehrer, N.B. Isolation of Sporothrix schenckii in the soil in Israel in relation to a new case in man. Sabouraudia 1976, 14, 217-222. [CrossRef] [PubMed]

21. Munguía, P.R.; Romo, L.Y.; Castañeda, R.E.; Velázquez, E.M.C.; Espinosa, T.A. Sporotrichosis epidemiology in Huauchinango, Puebla. Enferm. Infecc. Microbiol. 2007, 27, 38-43. (In Spanish)

22. Sánchez-Alemán, M.A.; Araiza, J.; Bonifaz, A. Aislamiento y caracterización de cepas silvestres de Sporotrhix schenkii e investigación de reactores a la Esporototicina. Gac. Med. Mex. 2004, 140, 507-512. (In Spanish) [PubMed]

23. Espinosa Texis, A.P.; Castillo-Hernández, D.; Díaz-Hernández, M.; Hernández-Hernández, F. Presence in soil and plants of potential agents causing human subcutaneous infections in the state of Puebla, Mexico. Terra Latinoam. 2017, 35, 113-122. (In Spanish) [CrossRef]

24. Mayorga-Rodríguez, J.A.; Martínez- López, D.A.; Méndez-Guardado, P. Isolation of Sporothrix schenckii in nature (soil and plants). Med. Cutanea Iber. Lat. Am. 2017, 99, 25-28. (In Spanish)

25. Madrid, H.; Cano, J.; Gené, J.; Bonifaz, A.; Toriello, C.; Guarro, J. Sporothrix globosa, a pathogenic fungus with widespread geographical distribution. Rev. Iberoam. Micol. 2009, 26, 218-222. [CrossRef] [PubMed]

26. Findlay, G.H.; Vismer, H.F. Studies in sporotrichosis: Fungal morphogenesis and pathogenicity in differing environments. Mycopathologia 1986, 96, 115-122. [CrossRef] [PubMed]

27. Govender, N.P.; Maphanga, T.G.; Zulu, T.G.; Patel, J.; Walaza, S.; Jacobs, C.; Ebonwu, J.I.; Ntuli, S.; Naicker, S.D.; Thomas, J. An Outbreak of Lymphocutaneous Sporotrichosis among Mine-Workers in South Africa. PLoS Negl. Trop. Dis. 2015, 9, e0004096. [CrossRef] [PubMed]

28. De Meyer, E.M.; de Beer, Z.W.; Summerbell, R.C.; Moharram, A.M.; de Hoog, G.S.; Vismer, H.F.; Wingfield, M.J. Taxonomy and phylogeny of new wood- and soil-inhabiting Sporothrix species in the Ophiostoma stenoceras-Sporothrix schenckii complex. Mycologia 2008, 100, 647-661. [CrossRef] [PubMed]

29. McDonough, E.S.; Lewis, A.L.; Meister, M. Sporothrix (Sporotrichum) schenckii in a Nursery Barn Containing Sphagnum. Public Health Rep. 1970, 85, 579-586. [CrossRef] [PubMed]

30. Coles, F.B.; Schuchat, A.; Hibbs, J.R.; Kondracki, S.F.; Salkin, I.F.; Dixon, D.M.; Chang, H.G.; Duncan, R.A.; Hurd, N.J.; Morse, D.L. A Multistate Outbreak of Sporotrichosis associated with Sphagnum Moss. Am. J. Epidemiol. 1992, 136, 475-487. [CrossRef] [PubMed]

31. Kenyon, E.M.; Russell, L.H.; McMurray, D.N. Isolation of Sporothrix schenckii from potting soil. Mycopathologia 1984, 87, 128. [CrossRef] [PubMed]

32. Mackinnon, J.E.; Conti-Díaz, I.A.; Gezuele, E.; Civila, E.; da Luz, S. Isolation of Sporothrix schenckii from nature and considerations on its pathogenicity and ecology. Sabouraudia 1969, 7, 38-45. [CrossRef] [PubMed]

33. Mendoza, M.; Diaz, E.; Alvarado, P.; Romero, E.; Bastardo de Albornoz, M.C. [Isolation of Sporothrix schenckii from environmental samples in Venezuela]. Rev. Iberoam. Micol. 2007, 24, 317-319. (In Spanish) [CrossRef]

34. Rodrigues, A.M.; de Hoog, G.S.; de Camargo, Z.P. Sporothrix Species Causing Outbreaks in Animals and Humans Driven by Animal-Animal Transmission. PLoS Pathog. 2016, 12, e1005638. [CrossRef] [PubMed] 
35. Madrid, H.; Gené, J.; Cano, J.; Silvera, C.; Guarro, J. Sporothrix brunneoviolacea and Sporothrix dimorphospora, two new members of the Ophiostoma stenoceras-Sporothrix schenckii complex. Mycologia 2010, 102, 1193-1203. [CrossRef] [PubMed]

36. De Bièvre, C.; Mariat, F. Ecological and epidemiological relationships between Sporothrix schenckii, a fungus pathogenic for man and the Ceratocystis genus. Bull. Soc. Pathol. Exot. Fil. 1978, 71, 203-210.

37. Pasarell, L.; McGinnis, M.R. Viability of fungal cultures maintained at -70 degrees C. J. Clin. Microbiol. 1992, 30, 1000-1004. [PubMed]

38. Buzoleva, L.S. The multiplication dynamics of pathogenic bacteria in relation to the trophic and temperature cultivation conditions. Zhurnal Mikrobiol. Epidemiol. Immunobiol. 2000, 2, 15-18.

39. Torres-Guerrer, H.; Arenas-López, G. UV irradiation induced high frequency of colonial variants with altered morphology in Sporothrix schenckii. Med. Mycol. 1998, 36, 81-87. [CrossRef] [PubMed]

40. Lacerda, C.M.; Martins, E.M.; de Resende, M.A.; de Andrade, A.S. Gamma radiation effects on Sporothrix schenckii yeast cells. Mycopathologia 2011, 171, 395-401. [CrossRef] [PubMed]

41. Casadevall, A.; Steenbergen, J.N.; Nosanchuk, J.D. 'Ready made' virulence and 'dual use' virulence factors in pathogenic environmental fungi-The Cryptococcus neoformans paradigm. Curr. Opin. Microbiol. 2003, 6, 332-337. [CrossRef]

42. Wang, Y.; Casadevall, A. Decreased susceptibility of melanized Cryptococcus neoformans to UV light. Appl. Environ. Microbiol. 1994, 60, 3864-3866. [PubMed]

43. Wang, Y.; Casadevall, A. Susceptibility of melanized and nonmelanized Cryptococcus neoformans to nitrogenand oxygen-derived oxidants. Infect. Immun. 1994, 62, 3004-3007. [PubMed]

44. Rosas, A.L.; Casadevall, A. Melanization affects susceptibility of Cryptococcus neoformans to heat and cold. FEMS Microbiol. Lett. 1997, 153, 265-272. [CrossRef]

45. Rosas, A.L.; Casadevall, A. Melanization decreases the susceptibility of Cryptococcus neoformans to enzymatic degradation. Mycopathologia 2001, 151, 53-56. [CrossRef] [PubMed]

46. Taborda, C.P.; da Silva, M.B.; Nosanchuk, J.D.; Travassos, L.R. Melanin as a virulence factor of Paracoccidioides brasiliensis and other dimorphic pathogenic fungi: A minireview. Mycopathologia 2008, 165, 331-339. [CrossRef] [PubMed]

47. Almeida-Paes, R.; Cardoso de Oliveira, L.; Evangelista-Oliveira, M.M.; Gutierrez-Galhardo, M.C.; Nosanchuk, J.D.; Zancopé-Oliveira, R.M. Phenotypic characteristics associated with virulence of clinical isolates from the Sporothrix complex. BioMed Res. Int. 2015, 212308. [CrossRef]

48. Steenbergen, J.N.; Nosanchuk, J.D.; Malliaris, S.D.; Casadevall, A. Interaction of Blastomyces dermatitidis, Sporothrix schenckii, and Histoplasma capsulatum with Acanthamoeba castellanii. Infect. Immun. 2004, 72, 3478-3488. [CrossRef] [PubMed]

49. Gessler, N.N.; Egorova, A.S.; Belozerskaia, T.A. Melanin pigments of fungi under extreme environmental conditions (review). Prikl. Biokhimiia Mikrobiol. 2014, 50, 125-134.

50. Baumgardner, D.J. Soil-related bacterial and fungal infections. J. Am. Board Fam. Med. 2012, 25, 734-744. [CrossRef] [PubMed]

(C) 2018 by the authors. Licensee MDPI, Basel, Switzerland. This article is an open access article distributed under the terms and conditions of the Creative Commons Attribution (CC BY) license (http://creativecommons.org/licenses/by/4.0/). 